\title{
Biofilm production of coagulase-negative staphylococci isolated from rescued wild animals in the Republic of Korea
}

\author{
Sangjun Lee ${ }^{1}$, Jehwi Hwang ${ }^{1}$, Jongwoon Kim ${ }^{1}$, Joonyeop Lee ${ }^{1}$, Hong-Cheul Kim ${ }^{1}$, Haerin Rhim ${ }^{1,2}$ \\ and Jae-Ik Han ${ }^{1,2^{*}}$
}

\begin{abstract}
Biofilm production is a well-known causative factor of catheter- and medical device-related sepsis. Its high prevalence in coagulase-negative staphylococci (CoNS) has recently been reported. Information on biofilm production in CoNS isolated from wild animals is lacking. Herein, we studied the biofilm formation capabilities of CoNS isolated from rescued wild animals in the Republic of Korea. Swab samples were collected from the conjunctiva, nasal cavity, perianal area, and rectum for mammals while the sampling was done from the conjunctiva, oral mucosa, pericloacal area, and cloaca for birds. Isolation of CoNS was based on morphological and biochemical analyses along with molecular typing. Biofilm production was analyzed using 96-well plate based quantitative adherence assays. The studies demonstrated that CoNS of mammalian origin have higher biofilm-producing ability (70.4\%) than the isolates from birds (62.5\%). In particular, all methicillin-resistant (MR) CoNS isolated from mammals were capable of biofilm formation while only $63.3 \%$ of MR CoNS isolated from birds could produce biofilms. The MR CoNS isolated from mammals also had a significantly higher ability to form biofilms (100\%) than methicillin susceptible CoNS (60.0\%) than those isolates from birds. The findings show that wild animals may act as reservoirs as well as possible transmitters of biofilm-mediated antibiotic resistant genes.
\end{abstract}

Keywords: Methicillin resistance, Reservoir, Staphylococcus sciuri

\section{Findings}

The pathogenic potential of coagulase-negative staphylococci (CoNS) is well known; however, the potential causes and underlying mechanisms remain unclear. CoNS are nosocomial pathogens in humans, with Staphylococcus epidermidis and Staphylococcus haemolyticus being the most significant species [1]. They have also been isolated from a variety of farm animals, pets, and wild animals and CoNS are considered as a reservoir of antibiotic resistance genes [2,3]. Recently, CoNS isolates with high vancomycin resistance were discovered in the saliva of migratory songbirds in the USA [4], suggesting the zoonotic potential of CoNS originating from wild

\footnotetext{
*Correspondence: jihan@jbnu.ac.kr

${ }^{1}$ Laboratory of Wildlife Medicine, College of Veterinary Medicine, Jeonbuk

National University, Gobongro 79, Iksan 54596, Republic of Korea

Full list of author information is available at the end of the article
}

animals. Biofilm formation is a well-known pathogenic characteristic of CoNS that leads to catheter- and medical device-related sepsis $[5,6]$. Here we report methicillin resistance prevalence and biofilm formation abilities of CoNS isolated from rescued wild animals in the Republic of Korea.

From December 2016 to February 2017, 120 swab samples were collected from rescued wild animals at the Jeonbuk Wildlife Center. All samplings were done before the animals contacted any medical device or were given any medications. For mammals, samples were collected from the conjunctiva, nasal cavity, perianal area, and rectum, while the sampling was done from the conjunctiva, oral mucosa, pericloacal area, and cloaca of birds. After sampling, the swabs were spread onto trypticase soy agar plates containing $5 \%$ sheep blood and were subsequently incubated at $37^{\circ} \mathrm{C}$ for $24-48 \mathrm{~h}$. After incubation, CoNS were isolated based on the colony morphology, 
completion of hemolysis, Gram staining, a conventional catalase test with $5 \%$ hydrogen peroxide, coagulase test using EDTA-treated rabbit plasma (BBL Coagulase Plasma, rabbit with EDTA; BD, Sparks, MD, USA), and a DNase test using DNase test agar with methyl green (BD, Sparks, MD, USA). S. aureus strain ATCC 25923 (American Type Culture Collection [ATCC], Manassas, VA, USA) and a clinical isolate of $S$. epidermidis confirmed by species-specific polymerase chain reaction (PCR) [7] and sequencing were used as positive and negative controls for coagulase and DNase tests, respectively.

The isolated staphylococci were further identified by $16 \mathrm{~S}$ ribosomal RNA (16S rRNA) and heat shock protein 60 (hsp60) analyses [8-10] (Table 1). After PCR amplification, all amplicons were purified and sequenced. The homology between the deduced nucleotide sequences and a known $S$. epidermidis genomic sequence was analyzed using the BLAST search program (National Center for Biotechnology Information [NCBI], USA). Finally, the species identification of the isolates was confirmed by a multiple-PCR method [11].

Methicillin resistance of isolated CoNS was confirmed by the Kirby-Bauer disc diffusion test with a $1 \mu \mathrm{g}$ oxacillin disc (Oxoid, Hampshire, UK) and a 30- $\mu$ g cefoxitin disc (Oxoid) and a PCR assay targeting the mecA gene [12]. A methicillin resistant (MR) strain (ATCC 25923) and a methicillin susceptible (MS) strain (ATCC 6538) of S. aureus were used as controls for these tests.

Biofilm formation ability of the isolated S. epidermidis strains was determined through a quantitative adherence assay using 96-well tissue culture plates [13]. Briefly, the isolate from fresh trypticase soy agar with $5 \%$ sheep blood was inoculated in trypticase soy broth (TSB) and incubated for $24 \mathrm{~h}$ at $37^{\circ} \mathrm{C}$ under stationary and aerobic

Table 1 Frequency of coagulase negative staphylococci isolation from wild mammals and birds in the Republic of Korea

\begin{tabular}{|c|c|c|c|}
\hline & Animal species (scientific name) & Sampling site & Staphylococcus sp. (number of isolates) \\
\hline \multirow[t]{9}{*}{ Mammals $(n=16)$} & \multirow[t]{4}{*}{ Korean water deer (Hydropotes inermis, $n=11$ ) } & Conjunctiva & $\begin{array}{l}\text { S. sciuri (3), S. delphini (3), S. caseolyticus (1), S. chromogenes (1), } \\
\text { S. lentus (1), S. warneri (1) }\end{array}$ \\
\hline & & Nasal cavity & $\begin{array}{l}\text { S. muscae (2), S. chromogenes (1), S. haemolyticus (1), S. vitulus } \\
\text { (1) }\end{array}$ \\
\hline & & Perianal & S. warneri (1) \\
\hline & & Rectum & S. hominis (1), S. muscae (1), S. sciuri (1) \\
\hline & \multirow[t]{3}{*}{ Raccoon dog (Nyctereutes procyonoides, $n=4$ ) } & Conjunctiva & S. caseolyticus (2) \\
\hline & & Nasal cavity & S. caseolytics (1), S. sciuri (1) \\
\hline & & Perianal & S. haemolyticus (2) \\
\hline & \multirow[t]{2}{*}{ Leopard cat (Prionailurus bengalensis, $\mathrm{n}=1$ ) } & Conjunctiva & S. felis (1) \\
\hline & & Nasal cavity & S. felis (1) \\
\hline \multirow[t]{21}{*}{ Birds $(n=23)$} & \multirow[t]{4}{*}{ Black-tailed gull (Larus crassirostris, $\mathrm{n}=3$ ) } & Conjunctiva & S. epidermidis (1), S. sciuri (1) \\
\hline & & Nasal cavity & S. sciuri (4) \\
\hline & & Perianal & S. haemolytics (1) \\
\hline & & Cloaca & S. haemolytics (1) \\
\hline & Ring-necked pheasant (Phasianus colchicus, $n=1$ ) & Oral mucosa & S. sciuri (1) \\
\hline & \multirow[t]{5}{*}{ Common buzzard (Buteo buteo, $\mathrm{n}=7$ ) } & Conjunctiva & S. epidermidis (1), S. delphini (1) \\
\hline & & Nasal cavity & S. sciuri (3), S. cohnii (1), S. kloosii (1) \\
\hline & & Oral mucosa & S. sciuri (3) \\
\hline & & Perianal & S. warneri (7) \\
\hline & & Cloaca & S. warneri (4) \\
\hline & \multirow[t]{2}{*}{ Oriental turtle dove (Streptopelia orientalis, $\mathrm{n}=2$ ) } & Conjunctiva & S. sciuri (1) \\
\hline & & Oral mucosa & S. sciuri (2) \\
\hline & \multirow[t]{4}{*}{ Brown hawk-owl (Ninox scutulata, $\mathrm{n}=6$ ) } & Conjunctiva & S. cohnii (1), S. sciuri (1) \\
\hline & & Nasal cavity & S. sciuri (4), S. cohnii (2), S. haemolyticus (2) \\
\hline & & Perianal & S. haemolyticus (1), S. xylosus (1) \\
\hline & & Cloaca & S. epidermidis (1), S. haemolyticus (1), S. xylosus (1) \\
\hline & \multirow[t]{2}{*}{ Tawny owl (Strix aluco, $\mathrm{n}=2$ ) } & Conjunctiva & S. xylosus (2) \\
\hline & & Oral mucosa & S. sciuri (1), S. vitulus (1), S. xylosus (1) \\
\hline & \multirow[t]{2}{*}{ Gray heron (Ardea cinerea, $\mathrm{n}=1$ ) } & Conjunctiva & S. delphini (1) \\
\hline & & Oral mucosa & S. delphini (1) \\
\hline & Northern goshawk (Accipiter gentilis, $\mathrm{n}=1$ ) & Nasal cavity & S. xylosus (1) \\
\hline
\end{tabular}


conditions. After incubation, the broth was diluted to the ratio of 1:100 in TSB containing $2 \%$ glucose to maximize ica operon induction [14]. A total of $200 \mu \mathrm{L}$ of the cell suspension was subsequently transferred to a U-bottomed 96-well microtiter plates and incubated aerobically for $24 \mathrm{~h}$ at $37^{\circ} \mathrm{C}$. The culture was then removed from the wells, and the plates were washed thrice with $200 \mu \mathrm{L}$ of phosphate-buffered saline to remove non-adherent cells followed by drying of the plates in an inverted position. Adherent biofilms were fixed with $95 \%$ ethanol and stained with $100 \mu \mathrm{L}$ of $1 \%$ crystal violet for $5 \mathrm{~min}$. Unbound crystal violet was subsequently removed, and the wells were washed thrice with $300 \mu \mathrm{L}$ of sterile distilled water. The water was then removed, and the plate was air-dried for $2 \mathrm{~h}$. The optical density (OD) of each well was measured at $570 \mathrm{~nm}\left(\mathrm{OD}_{570}\right)$. The analyses were performed in triplicate, and the isolates were classified as strong, moderate, weak, or zero biofilm producers based on their $\mathrm{OD}_{570}\left(4 \times \mathrm{OD}_{\mathrm{c}}<\mathrm{OD}_{570}\right.$ : strong biofilm producer; $2 \times \mathrm{OD}_{\mathrm{c}}<\mathrm{OD}_{570} \leq 4 \times \mathrm{OD}_{\mathrm{c}}$ : moderate biofilm producer; $\mathrm{OD}_{\mathrm{c}}<\mathrm{OD}_{570} \leq 2 \times \mathrm{OD}_{\mathrm{c}}$ : weak biofilm producer; $\mathrm{OD}_{570} \leq \mathrm{OD}_{\mathrm{c}}:$ no biofilm producer $\left[\mathrm{OD}_{\text {cutoff }}\left(\mathrm{OD}_{\mathrm{c}}\right)=\right.$ average $\mathrm{OD}_{570}$ of negative control $+(3 \times$ standard deviation of negative control)]) [15]. S. aureus strain ATCC25923 and sterile TSB were used as positive and negative controls, respectively.

From 120 swab samples, 83 CoNS isolates were obtained. Of these, 27 were isolated from 16 wild mammals, while 56 were isolated from 23 wild birds (Table 1). S. sciuri was the most commonly isolated species in both mammals and birds. In birds, S. warneri was the second most commonly isolated species $(\mathrm{n}=11)$, while $S$. caseolyticus $(\mathrm{n}=4)$ was the second most common species isolated from mammalian samples. Moreover, all $S$. sciuri isolates $(\mathrm{n}=5)$ from mammals were MR, while 18 out of 21 S. sciuri (85.7\%) samples isolated from birds were MR. Regardless of the origin of the sample, methicillin resistance of CoNS isolates from birds (53.6\%) was much higher than that of CoNS isolated from mammals (25.9\%).

The biofilm assay results revealed that all CoNS isolated from mammals could form biofilms. This was not associated with methicillin resistance. Among the mammalian MR CoNS, strong or moderate biofilm production was found, while only $60 \%$ of mammalian MS CoNS (12/20) were found as strong or moderate

Table 2 Results of biofilm production assays of 83 coagulase negative staphylococci isolates

\begin{tabular}{|c|c|c|c|c|c|c|}
\hline Animal & Sample origin & $\begin{array}{l}\text { Methicillin } \\
\text { resistance (No.) }\end{array}$ & Mean $\mathrm{OD}_{570} \pm \mathrm{SD}$ & $\begin{array}{l}\text { No. (\%) of strong or moderate } \\
\text { biofilm producer }\end{array}$ & $\begin{array}{l}\text { No. (\%) of mild } \\
\text { biofilm producer }\end{array}$ & $\begin{array}{l}\text { No. (\%) of non- } \\
\text { biofilm producer }\end{array}$ \\
\hline \multirow[t]{10}{*}{ Mammals } & Conjunctive & $\mathrm{R}(3)$ & $0.426 \pm 0.006$ & $3(100)$ & $0(0)$ & $0(0)$ \\
\hline & & $S(10)$ & $0.412 \pm 0.032$ & $6(60.0)$ & $4(40.0)$ & $0(0)$ \\
\hline & Nasal cavity & $R(2)$ & $1.933 \pm 0.048$ & $2(100)$ & $0(0)$ & $0(0)$ \\
\hline & & $S(6)$ & $0.134 \pm 0.025$ & $2(33.3)$ & $4(66.7)$ & $0(0)$ \\
\hline & Perianal & $\mathrm{R}(1)$ & $0.551 \pm 0.050$ & $1(100)$ & $0(0)$ & $0(0)$ \\
\hline & & $S(2)$ & $0.265 \pm 0.083$ & $2(100)$ & $0(0)$ & $0(0)$ \\
\hline & Rectum & $\mathrm{R}(1)$ & $0.792 \pm 0.028$ & $1(100)$ & $0(0)$ & $0(0)$ \\
\hline & & $S(2)$ & $0.319 \pm 0.021$ & $2(100)$ & $0(0)$ & $0(0)$ \\
\hline & Total & $\mathrm{R}(7)$ & $0.926 \pm 0.027$ & $7(100)$ & $0(0)$ & $0(0)$ \\
\hline & & $S(20)$ & $0.305 \pm 0.028$ & $12(60.0)$ & $8(40.0)$ & $0(0)$ \\
\hline \multirow[t]{14}{*}{ Birds } & Cloaca & $R(0)$ & - & - & - & - \\
\hline & & $S(3)$ & $0.188 \pm 0.013$ & $2(66.7)$ & $1(33.3)$ & $0(0)$ \\
\hline & Conjunctiva & $\mathrm{R}(6)$ & $0.253 \pm 0.027$ & $3(50.0)$ & $3(50.0)$ & $0(0)$ \\
\hline & & $S(4)$ & $0.284 \pm 0.018$ & $3(75.0)$ & $1(25.0)$ & $0(0)$ \\
\hline & Nasal cavity & $R(15)$ & $0.427 \pm 0.096$ & $8(53.3)$ & $6(40.0)$ & $1(6.7)$ \\
\hline & & $S(3)$ & $0.336 \pm 0.099$ & 1 (33.3) & $1(33.3)$ & $1(33.3)$ \\
\hline & Oral mucosa & $R(5)$ & $1.003 \pm 0.512$ & $5(100)$ & $0(0)$ & $0(0)$ \\
\hline & & $S(5)$ & $0.506 \pm 0.126$ & $5(100)$ & $0(0)$ & $0(0)$ \\
\hline & Pericloacal & $R(2)$ & $0.134 \pm 0.008$ & $1(50.0)$ & $1(50.0)$ & $0(0)$ \\
\hline & & $\mathrm{S}(8)$ & $0.239 \pm 0.038$ & $2(25.0)$ & $6(75.0)$ & $0(0)$ \\
\hline & Rectum & $\mathrm{R}(2)$ & $0.479 \pm 0.176$ & $2(100)$ & $0(0)$ & $0(0)$ \\
\hline & & $\mathrm{S}(3)$ & $1.186 \pm 0.407$ & $3(100)$ & $0(0)$ & $0(0)$ \\
\hline & Total & $\mathrm{R}(30)$ & $0.472 \pm 0.125$ & $19(63.3)$ & $10(33.3)$ & $1(3.3)$ \\
\hline & & $S(26)$ & $0.412 \pm 0.099$ & $16(61.5)$ & $9(34.6)$ & $1(3.8)$ \\
\hline
\end{tabular}


biofilm producers. Thus, a significant difference in the prevalence of strong or moderate biofilm production was observed between mammalian-origin MR and MS CoNS $(\mathrm{P}<0.001$, independent $t$ test). This finding differs from observations on MR and MS Staphylococcus pseudintermedius isolated from companion dogs in Republic of Korea, indicating no difference of biofilmproducing abilities between MR and MS S. pseudintermedius [16]. In birds, 96.4\% (54/56) CoNS could form biofilm regardless of methicillin resistance, and $62.5 \%$ $(35 / 56)$ of the CoNS demonstrated strong or moderate biofilm production ability. Table 2 summarizes the results of the biofilm production assay.

Most of the CoNS isolated from wild animals were capable of biofilm production, with $65.1 \%$ being classified as either strong or moderate biofilm producers. This data indicates relatively lower prevalence of biofilm producing CoNS in wild animals than in companion animals [1618]. However, considering that all wild animals evaluated in this study seem to have no prior exposure to antibiotic therapy, this prevalence indicates a wider spread of the biofilm-producing bacteria in the environment. This also implies that subsequent to the acquisition of the antibiotic resistant genes or pathogenic factors by horizontal spread among biofilm-producing staphylococci, wild animals could act as reservoirs and transmitters of these genes or factors $[19,20]$.

In summary, this study demonstrates the high prevalence of biofilm-producing CoNS in wild animals, indicating the necessity for investigation and management of the wild environment and animals. A future large-scale investigation is necessary to understand and establish effective management strategies.

\section{Abbreviations}

16S rDNA: 16 S ribosomal RNA gene; CoNS: coagulase-negative staphylococci; Hsp60: heat shock protein 60; MR: methicillin resistant; MS: methicillin susceptible; OD: optical density; TSB: trypticase soy broth.

\section{Acknowledgements}

We thank Mrs. Sun-Young Kim for technical assistance.

\section{Prior publication}

Data has not been published previously.

\section{Authors' contributions}

SL performed the bacterial identification and biofilm assay and interpreted the data. JH and JK participated in the bacterial identification and biofilm assay. JL performed the methicillin resistance tests. HCK and HR collected the swab samples, and isolated the CoNS. JH, who designed the experiments and drafted the manuscript, had primary responsibility of the study as the head of the project. All authors read and approved the final manuscript.

\section{Funding}

This study was supported by the National Research Foundation of Korea (NRF) Grant funded by the Korean Government (MOE; No. 2016R1D1A3B03932480) and also supported by the Korea Ministry of Environment (MOE) Public Technology Program based on Environmental Policy (No. 2016000210002).

\section{Availability of data and materials}

The datasets used and/or analyzed during the current study are available from the corresponding author on reasonable request.

Ethics approval and consent to participate

Not applicable.

\section{Consent for publication}

Not applicable.

\section{Competing interests}

The authors declare that they have no competing interests.

\section{Author details}

${ }^{1}$ Laboratory of Wildlife Medicine, College of Veterinary Medicine, Jeonbuk National University, Gobongro 79, Iksan 54596, Republic of Korea. ${ }^{2}$ Jeonbuk Wildlife Center, Jeonbuk National University, Gobongro 79, Iksan 54596, Republic of Korea.

Received: 16 February 2019 Accepted: 17 October 2019

Published online: 24 October 2019

\section{References}

1. Becker K, Heilmann C, Peters G. Coagulase-negative staphylococci. Clin Microbiol Rev. 2014;27:870-926.

2. Regecová I, Pipová M, Jevinová P, Kmet V, Výrostková J, Sopková D, et al. Antimicrobial resistance of coagulase-negative species of staphylococci isolated from the meat of wild pheasants (Phasianus colchicus). Ital J Anim Sci. 2014:13:627-30

3. Perreten V, Giampa N, Schuler-Schmid U, Teuber M. Antibiotic resistance genes in coagulase-negative staphylococci isolated from food. Syst Appl Microbiol. 1998;21:113-20.

4. Ishihara S, Bitner JJ, Farley GH, Gillock ET. Vancomycin-resistant grampositive cocci isolated from the saliva of wild songbirds. Curr Microbiol. 2013;66:337-43.

5. Nadell CD, Xavier JB, Foster KR. The sociobiology of biofilms. FEMS Microbiol Rev. 2009;33:206-24.

6. O'Gara JP, Humphreys H. Staphylococcus epidermidis biofilms: importance and implications. J Med Microbiol. 2001;50:582-7.

7. Martineau F, Picard FJ, Grenier L, Roy PH, Ouellette M, Bergeron MG. Multiplex PCR assays for the detection of clinically relevant antibiotic resistance genes in staphylococci isolated from patients infected after cardiac surgery. The ESPRITTrial. J Antimicrob Chemother. 2000;46:527-34.

8. Hill JE, Town JR, Hemmingsen SM. Improved template representation in cpn60 polymerase chain reaction (PCR) product libraries generated from complex templates by application of a specific mixture of PCR primers. Environ Microbiol. 2006:8:741-6.

9. Lane DJ, Pace B, Olsen GJ, Stahl DA, Sogin ML, Pace NR. Rapid determination of 165 ribosomal RNA sequences for phylogenetic analyses. Proc Natl Acad Sci USA. 1985;82:6955-9.

10. Petti CA, Brandt ME, Church DL, Emler S, Simmon K, Zelazny AM. Interpretive criteria for identification of bacteria and fungi by targeted DNA sequencing. Wayne: Clinical and Laboratory Standards Institute; 2018. p. 7-9.

11. Sasaki T, Tsubakishita S, Tanaka Y, Sakusabe A, Ohtsuka M, Hirotaki S, et al. Multiplex-PCR method for species identification of coagulase-positive staphylococci. J Clin Microbiol. 2010;48:765-9.

12. Zhang K, McClure JA, Elsayed S, Louie T, Conly JM. Novel multiplex PCR assay for characterization and concomitant subtyping of staphylococcal cassette chromosome mec type I to V in methicillin-resistant Staphylococcus aureus. J Clin Microbiol. 2005;43:5026-33.

13. Christensen GD, Simpson WA, Younger JJ, Baddour LM, Barrett FF, Melton DM, et al. Adherence of coagulase-negative staphylococci to plastic tissue culture plates: a quantitative model for the adherence of staphylococci to medical devices. J Clin Microbiol. 1985;22:996-1006.

14. Rachid S, Ohlsen K, Wallner U, Hacker J, Hecker M, Ziebuhr W. Alternative transcription factor sigma(B) is involved in regulation of biofilm 
expression in a Staphylococcus aureus mucosal isolate. J Bacteriol. 2000;182:6824-6.

15. Stephanovićh S, Vuković D, Hola V, Di Bonaventura G, Djukić S, Cirković I, et al. Quantification of biofilm in microtiter plates: overview of testing conditions and practical recommendations for assessment of biofilm production by staphylococci. APMIS. 2007;115:891-9.

16. Han Jl, Yang CH, Park HM. Emergence of biofilm-producing Staphylococ cus pseudintermedius isolated from healthy dogs in South Korea. Vet Q. 2015:35:207-10

17. Dicicco M, Neethirajan S, Singh A, Weese JS. Efficacy of clarithromycin on biofilm formation of methicillin-resistant Staphylococcus pseudintermedius. BMC Vet Res. 2012;8:225.

18. Osland AM, Vestby LK, Fanuelsen H, Slettemeås JS, Sunde M. Clonal diversity and biofilm-forming ability of methicillin-resistant Staphylococcus pseudintermedius. J Antimicrob Chemother. 2012;67:841-8.
19. Savage VJ, Chopra I, O'Neill AJ. Staphylococcus aureus biofilms promote horizontal transfer of antibiotic resistance. Antimicrob Agents Chemother. 2013;57:1968-70.

20. Áquila-Arcos S, Álvarez-Rodríguez I, Garaiyurrebaso O, Garbisu C, Grohmann E, Alkorta I. Biofilm-forming clinical Staphylococcus isolates harbor horizontal transfer and antibiotic resistance genes. Front Microbiol. 2018;8:1-12.

\section{Publisher's Note}

Springer Nature remains neutral with regard to jurisdictional claims in published maps and institutional affiliations.
Ready to submit your research? Choose BMC and benefit from:

- fast, convenient online submission

- thorough peer review by experienced researchers in your field

- rapid publication on acceptance

- support for research data, including large and complex data types

- gold Open Access which fosters wider collaboration and increased citations

- maximum visibility for your research: over $100 \mathrm{M}$ website views per year

At BMC, research is always in progress.

Learn more biomedcentral.com/submissions 